\title{
MENINGKATKAN MOTIVASI SISWA GUNA MENEMPUH JENJANG PENDIDIKAN YANG LEBIH TINGGI
}

\author{
Sampir Andrean Sukoco \\ Progam Studi Ilmu Administrasi Bisnis \\ STIA Pembangunan Jember \\ *Email: andreansukoco@gmail.com
}

\begin{abstract}
ABSTRAK
Pengabdian adalah salah satu bagian dari Tri Darma Perguruan Tinggi yang wajib dilakukan oleh seorang tenaga pendidik. Tujuan pengabdian ini adalah meningkatkan motivasi siswa guna menempuh jenjang pendidikan yang lebih tinggi. Pengabdian ini dilakukan di SMK APM (Asrama Pembina Masyarakat) pada kelas V dan V1. Metode yang digunakan dalam kegiatan ini adalah melalui seminar classes dengan model sosialisasi/ceramah dan tanya jawab. Kegiatan pengabdian ini dilakukan sekali, dan dilaksanakan pada 26 April 2019. Hasil dari pengabdian dengan tema peningkatan motivasi siswa guna menempuh jenjang pendidikan yang lebih tinggi adalah bahwa para siswa termotivasi untuk melanjutkan kejenjang ke perguruan tinggi. Para siswa memahami bahwa mengenyam pendidikan tinggi sangat penting bagi diri sendiri maupun bagi negara.

Kata kunci : motivasi, pendidikan tinggi
\end{abstract}




\section{Analisis Situasi}

Tujuan umum pendidikan Indonesia terangkai dalam tujuan pembentukan negara RI, yaitu melindungi segenap bangsa Indonesia dan seluruh tumpah darah Indonesia, memajukan kesejahteraan umum, mencerdaskan kehidupan bangsa, dan ikut melaksanakan ketertiban dunia. Rumusan ini adalah cita-cita yang menjadi arah sekaligus basis pengukuran berbagai upaya dan kinerja kebangsaan, terutama pendidikan sebagai episentrumnya. Pendidikan adalah proses belajar menjadi manusia seutuhnya dengan mempelajari dan mengembangkan kehidupan (mikro-kosmos dan makro-kosmos) sepanjang hidup. Dalam mempelajari dan mengembangkan kehidupan ini, manusia diperantarai sekaligus membentuk kebudayaan, yakni sistem nilai, sistem pengetahuan dan sistem perilaku bersama sebagai hasil daya pikir, daya rasa, daya karsa, dan daya raga bersama yang membentuk lingkungan sosial yang mempengaruhi cara manusia berperilaku dan memaknai dunianya (Tim PGRI, 2014:7).
Menurut data dalam Education For All (EFA) yang diterbitkan oleh Data Monitoring Report tahun 2011 yang dikeluarkan oleh Organisasi Pendidikan, Ilmu Pengetahuan, dan Kebudayaan Perserikatan Bangsa Bangsa (UNESCO) yang diluncurkan di New York, rangking mutu pendidikan di Indonesia menempati posisi 69 dari 127 negara di dunia. Rangking Indonesia kalah jauh dengan negara tentangga Brunei Darussalam yang menempati rangking ke 34 . Kriteria penilaian dari EFA tersebut didasarkan pada 1) angka partisipasi pendidikan dasar 2) angka melek huruf untuk mereka yang berusia 15 tahun keatas 3) angka partisipasi untuk kesetaraan gender, dan 4) angka bertahan siswa sampai kelas V Sekolah Dasar (Tim Ahli Seknas Jokowi, 2014:481).

Data yang lain pada tahun 2018, Bank Dunia (World Bank) menyebut bahwa kualitas pendidikan di Indonesia masih rendah, meski perluasan akses pendidikan untuk masyarakat dianggap sudah meningkat cukup signifikan. Indonesia sendiri telah 
mencanangkan program reformasi pendidikan untuk membenahi kualitas sektor ini selama 15 tahun sejak 2002. Kepala Perwakilan Bank Dunia untuk Indonesia Rodrigo Chaves mengatakan kualitas pendidikan yang rendah tercermin dari peringkat Indonesia yang masih berada di posisi tertinggi dari negaranegara tetangga. Indikator peringkat kualitas pendidikan ini tercermin dalam jumlah kasus buta huruf. Perbandingan dengan negara Vietnam, 55 persen anak usia 15 tahun di Indonesia secara fungsional buta huruf, dibandingkan kurang dari 10 persen di Vietnam. Bank Dunia melihat masih ada sejumlah tantangan yang masih belum terselesaikan, misalnya tidak meratanya akses pendidikan (https://www.cnnindonesia.com/gaya -hidup/20180607113429-284-

304214/bank-dunia-kualitaspendidikan-indonesia-masih-rendah, diakses pada tanggal 11 April 2019 pukul 22.14 WIB)

Indonesia termasuk negara yang mempunyai tingkat kelahiran yang tinggi di mana generasi muda adalah harapan kita untuk mengembangkan negara ini dan harapannya mereka juga meraih pendidikan setinggi-tingginya. Tapi di era globalisasi telah mengubah cara berpikir masyarakat, yang cenderung meninggalkan budaya ketimuran. Pada saat inilah pendidikan menjadi penting. Pendidikan merupakan salah satu faktor penting kewibawaan sebuah negara didapatkan. Dengan pendidikan yang baik pastinya akan melahirkan generasi penerus bangsa yang cerdas dan kompeten dalam bidangnya. Sehingga kondisi bangsa akan terus mengalami perbaikan dengan adanya para penerus generasi bangsa yang mumpuni dalam berbagai ilmu. Pendidikan adalah suatu hak dan kewajiban yang harus dilaksanakan oleh setiap manusia yang ada di dunia ini. (https://student.cnnindonesia.com/ed ukasi/20180103112420-445-

266335/ada-apa-dengan-pendidikandi-indonesia, diakses pada tanggal 11 April 2019 pukul 21.56 WIB).

Oleh karena itu, pendidikan merupakan hal yang paling dasar dan pokok di dalam kehidupan kita sehari-hari. Melalui pendidikan kita 
mampu menciptakan berbagai aspek dan keinginan didalam kehidupan. Pendidikanlah yang mampu melahirkan generasi yang cerdas dan berbudi baik. Semakin banyak masyarakat yang dapat mengenyam pendidikan, semakin baik pula pola pemikiran masyarakat. Terlebih jika dapat mengenyam pendidikan sampai ke jenjang perguruan tinggi.

Langeveld dalam bukunya yang disitir oleh Kurniadin dan Machali tahun 2016 mengatakan bahwasannya pendidikan merupakan setiap usaha, pengaruh, perlindungan, dan bantuan yang diberikan kepada anak tertuju kepada pendewasaan anak itu, cakap melaksanakan tugas hidupnya sendiri. Pengaruh itu datangnya dari orang dewasa (atau orang yang diciptakan oleh orang dewasa seperti sekolah, buku, putaran hidup seharihari, dan sebagainya) dan ditunjukkan kepada orang yang belum dewasa. Pendidikan sebagai tuntunan didalam hidup tumbuhnya anak-anak. Oleh karena itu maka dapat diartikan bahwa pendidikan adalah usaha sadar dan terencana, pengaruh, bantuan, dan perlindungan yang datang dari orang matang (mengerti) dan ditujukan kepada anak untuk dapat mendewasakan diri dan dapat dijadikan sebagai tuntunan didalam pertumbuhan hidup seorang siswa.

Pendidikan sangat penting bagi kemajuan bangsa. Bagaimana bangsa bisa selangkah lebih maju apabila para generasi muda tidak ingin melanjutkan pendidikan yang lebih tinggi. Keinginan dan kemauan yang kurang untuk melanjutkan pendidikan yang lebih tinggi sudah menjadi rahasia umum di negara kita ini. Masih banyak siswa yang tidak ingin melanjutkan ke jenjang perguruan tinggi dengan berbagai alasan yang berbeda-beda. Padahal untuk menjadi negara maju, syarat yang harus dipenuhi adalah memiliki Sumber Daya Manusia yang baik. Sumber Daya Manusia yang baik ini tentu adalah mereka yang memiliki pendidikan yang berkualitas.

Mayarakat yang berpendidikan tinggi akan lebih inovatif dan produktif dibandingkan masyarakat yang berpendidikan rendah. Oleh karena itu demi kemajuan suatu negara, maka sudah tentu harus memiliki 
masyarakat yang berpendidikan baik (tinggi). Indonesia sendiri masih belum optimal dalam hal pendidikan. Masih banyak masyarakat yang berpendidikan rendah, faktor klasik semangat generasi muda untuk menggapai pendidikan tinggi juga masih sangat rendah.

Fenomena yang ada pada SMK APM (Asrama Pendidikan Masyarakat) yang berada di J1 KH Abdul Hamid Gang IV No. 28 Desa Jatimulyo Kecamatan Jenggawah Kabupaten Jember Provinsi Jawa Timur juga menunjukkan trend seperti itu. Berdasarkan wawancara yang dilakukan dengan Kepala Sekolah SMK APM (Asrama Pendidikan Masyarakat), masih banyak siswa yang enggan untuk melanjutkan ke jenjang perguruan tinggi. Siswa lebih memilih bekerja setelah lulus dari SMK. Kurangnya minat lulusan siswa-siswi SMK APM (Asrama Pembina Masyarakat) untuk melanjutkan ke jenjang perguruan tinggi menjadi alasan untuk dilakukannya pengabdian masyarakat.

Seorang tenaga pendidik pada perguruan tinggi diwajibkan untuk melakukan Tri Darma (Pengajaran, Penelitian, dan Pengabdian Kepada Masyarakat). Oleh karena itu, merujuk pada fenomena permasalahan di SMK APM (Asrama Pembina Masyarakat) yang mana para siswa tidak ada motivasi untuk melanjutkan sekolah yang lebih tinggi, membuat tergerak bagi seorang tenaga pendidik untuk melakukan pengabdian masyarakat kepada para siswa-siswi SMK APM (Asrama Pembina Masyarakat) guna memotivasi siswa untuk dapat melanjutkan ke jenjang perguruan tinggi (kuliah).

\section{Landasan Teori}

\section{A. Motivasi}

Motivasi berasal dari kata move yang artinya bergerak. Definisi motivasi masih sering diperdebatkan. Diantaranya berbunyi motivasi adalah sesuatu yang menggerakkan atau mendorong seseorang atau kelompok orang, untuk melakukan atau tidak melakukan sesuatu. Salah satu unsur dari motivasi adalah motif, alasan, atau sesuatu yang memotivasi. Motivasi dapat dikelompokkan eksternal dan 
internal. Motivasi eksternal adalah motivasi yang berasal dari luar diri. Motivasi ini dibagi menjadi dua kelompok, yaitu motivasi eksternal positif dan motivasi eksternal negatif. Motivasi eksternal positif biasanya berupa hadiah, atau ajakan yang membangkitkan niat orang untuk berbuat sesuatu, misalnya upah, komisi, insentif, promosi dan sebagainya. Sedangkan motivasi eksternal negatif adalah sesuatu yang dipaksakan dari luar, agar orang menghindari sesuatu yang tidak diinginkan, misalnya sangsi, peraturan, tata tertib, termasuk ancaman. Selanjutnya dalah motivasi internal, definisinya adalah motivasi dari dalam diri sendiri. Jenis motivasi ini dapat dibagi menjadi dua kelompok juga, yaitu motivasi internal positif dan motivasi internal negatif. Kategori motivasi internal positif adalah dorongan karena ingin berkembang atau mengekspresikan diri. Contoh : ingin karir yang lebih baik, aktualisasi diri, dan sebagainya. Dan motivasi internal negatif muncul karena tekanan, ancaman ketakutan atau kekhawatiran. Misalnya adalah takut tertinggal oleh kelompok atau lingkungan, takut kehilangan, takut menderita, takut gagal, dan sebagainya (Irianto, 2005:55).

\section{B. Definisi Pendidikan}

Pengertian pendidikan menurut para pakar atau ahli pendidikan menurut kajian literatur dalam buku Neolaka dan Amalia (2017:11), sebagai berikut :

1. John Dewey, pendidikan adalah proses pembentukan kecakapan-kecakapan fundamental, emosional kearah alam, dan sesama manusia.

2. M.J. Langeveld, pendidikan adalah usaha, pengaruh, perlindungan dan bantuan yang diberikan kepada anak agar tertuju kepada kedewasaannya, atau lebih tepatnya membantu anak agar cukup cakap melaksanakan tugas hidupnya sendiri.

3. Thompson, pendidikan adalah pengaruh lingkungan terhadap individu untuk menghasilkan perubahanperubahan yang tetap dalam 
kebiasaan perilaku, pikiran, dan sifatnya.

4. Frederick J. McDonald, pendidikan adalah suatu proses atau kegiatan yang diarahkan untuk mengubah tabiat manusia.

5. H. Horne, pendidikan adalah proses yang terus menerus dari penyesuaian yang berkembang secara fisik dan mental yang sadar dan bebas kepada Tuhan.

\section{Pendidikan Tinggi}

Dewasa ini dapat disadari bahwa dalam era persaingan global, kelemahan kualitas sumber daya manusia merupakan ancaman nyata bagi bangsa Indonesia yang terkenal dengan kemajemukan masyarakat dan kualitasnya. Tantangan nasional yang aktual dan seharusnya kita dapat mewadahi dan menjawab tantanagan aktual dalam skala nasional melalui kepribadian dan integrasi nasional. Kontak budaya lain dan perubahan orientasi budaya menimbulkan dampak terhadap tata nilai masyarakat yang sedang menumbuhkan identitasnya sendiri sebagai bangsa. Semuanya itu menghadapkan masalah urgen berupa upaya memperkuat kepribaadian nasional. Selanjutnya adalah kewaspadaan nasional dan pembudayaan Pancasila. Dalam menyerap informasi dan nilai budaya yang selaras sangat membutuhkan adanya kewaspadaan dan kuatnya kepribadian bangsa. Selain itu yang lebih penting adalah kontribusi pendidikan terhadap pembangunan. Sektor ini memberikan makna bahwa keterkaitan pendidikan dengan program pembangunan dan keterikatan program pendidikan dengan pembangunan. Memasuki era globalisasi orang-orang seakan dituntut untuk menguasai pengatahuan dan kemampuan yang dapat digunakan sebagai modal utama dalam memasuki ekonomi pasar bebas, tujuannya tentu agar dapat berkompetisi dan sukses didalamnya. Sedangkan fungsi dari pendidikan tinggi dari task knowledge ke explisit knowledge yang diterbitkan, sehingga orang lain termotivasi untuk terus belajar (Afriantoni dkk, 2016:12). 
Menurut Neolaka dan Amalia (2017:62) pendidikan tinggi adalah pendidikan yang mempersiapkan peserta didik untuk menjadi anggota masyarakat yang memiliki tingkat kemampuan tinggi yang bersifat akademik, dan profesional (memiliki pengetahuan/knowledge, memiliki keterampilan/skill, dan memiliki sikap kerja yang baik dan benar. Di dalam Kepmendikbud Nomor 0186/P/1984, dikatakan bahwa pendidikan tinggi mempersiapkan peserta didik menjadi anggota masyarakat yang mempunyai kemampuan tinggi, bersifat akademik, profesional, sehingga dapat menerapkan, mengembangkan dan juga menciptakan ilmu pengetahuan, teknologi, dan seni dalam rangka pembangunan nasional, dan meningkatkan kesejahteraan manusia.

Penyelenggaraan sebuah perguruan tinggi dapat disamakan dengan penyelenggaraan sebuah negara atau kooperasi. Apabila dilihat sifat dan tujuan dasar penyelenggaraan pendidikan tinggi di suatu negara, bisa dengan cukup tegas mengatakan tidak. Pada dasarnya pendidikan tinggi yang pada praktiknya dijalankan oleh institusi perguruan tinggi dimaksudkan untuk dapat menjadi komunitas kaum intelektual suatu bangsa. Komunitas intelektual ini kemudian diharapkan untuk menjadi komunitas yang mampu menelurkan inovasi-inovasi dan pemikiranpemikiran dalam menghadapi permasalahan yang dihadapai okeh bangsa itu. Komunitas perguruan tinggi juga dijadikan sebuah garda moral dan penjaga nilai-niai luhur yang dianut oleh suatu bangsa, termasuk budaya, adat isitadat dan sebagainya. Dengan peranan dan harapan yang besar inilah kemudaian anggota komunitas. Pendidikann tinggi kemudian mendapat posisi yang terhormat di tengah msayarakat, gelar sebagai seorang sarjana merupakan gelar yang dipandang terhormat di tengah masyarakat karena seorang mahasiswa diharapkan berpengetahuan lebih dan berketrampilan lebih (Tajjudin, 2015:37). 
III. Identifikasi dan Perumusan Masalah

Para siswa SMK APM (Asrama Pembina Masyarakat) masih tergolong kurang antusias untuk bisa meneruskan ke jenjang perguruan tinggi. Permasalahan yang ada mereka terlalu pesimis untuk masa depan. Pesismis untuk bisa melanjutkan kuliah demi meraih karir yang baik. Masalah-masalah tersebut harus dicarikan solusinya agar mereka dapat termotivasi untuk melanjutkan sekolah ke jenjang pendidikan yang lebih tinggi.

Berdasarkan penjelasan di atas yang menjadi permasalahan dalam kegiatan pengabdian kepada masyarakat ini adalah bagaimana cara meningkatkan motivasi siswa untuk bisa meneruskan sekolah ke jenjang Perguruan Tinggi?

\section{Tujuan dan Manfaat Program}

Mengacu pada permasalahan di atas, maka tujuan kegiatan pengabdian kepada masyarakat ini adalah memberikan motivasi kepada siswa untuk bisa dan mau meneruskan ke jenjang pendidikan yang lebih tinggi (Perguruan Tinggi).
Adapun untuk manfaat dari kegiatan pengabdian kepada masyarakat ini adalah diharapkan para siswa untuk mau dan mampu meneruskan sekolah ke jenjang pendidikan yang lebih tinggi (Perguruan Tinggi).

\section{Deskripsi Program}

Metode yang digunakan dalam kegiatan ini adalah model ceramah berbentuk seminar classes yang dilaksanakan dengan memberikan komunikasi tatap muka kepada para siswa, sehingga antara pemateri dan peserta (siswa) dapat berdiskusi secara mendalam. Pembelajaran model ceramah dan diskusi tersebut dilakukan dengan beberapa materi yang disampaikan diantaranya membahas tentang data pendidikan di Indonesia, definisi pendidikan tinggi, dan pentingnya untuk meneruskan ke jenjang perguruan tinggi.

Pengabdian dilakukan pada hari Jumat, 26 April 2019 bertempat di SMK APM (Asrama Pembina Masyarakat) yang ada di Jl KH Abdul Hamid Gang IV No. 28 Desa Jatimulyo Kecamatan Jenggawah Kabupaten Jember Provinsi Jawa 
Timur, pada pukul $08.00-10.00$

WIB. Kegiatan ini diikuti oleh peserta dari siswa-siswi SMK APM (Asrama Pembina Masyarakat) yang berjumlah 50 siswa/ peserta.

$$
\text { Pengabdian masyarakat }
$$

dengan tema pendidikan yang berjudul "Meningkatkan Motivasi Siswa Guna Menempuh Jenjang Pendidikan Yang Lebih Tinggi" berlatang belakang dari rendahnya siswa SMK APM (Asrama Pembina Masyarakat) untuk mau meneruskan ke jenjang pendidikan yang lebih tinggi. Para siswa enggan untuk kuliah karena kurangnya motivasi. Dua alasan yang didapat ketika berdiskusi dengan para siswa diantaranya tidak mampu biaya dan ingin langsung bekerja. Padahal setidaknya dengan meneruskan kuliah ada 5 keuntungan yang akan didapat oleh para siswa nantinya, yaitu

1. Pengetahuan dan keterampilan akan semakin baik

2. Standart terendah pendidikan saat ini adalah jenjang S-1 (Strata 1)
3. Peluang kerja akan semakin besar

4. Dengan gelar sarjana maka derajat sebagai manusia akan lebih baik

5. Gelar Sarjana tentu dapat membuat karir dalam pekerjaan lebih baik

Oleh karena itu, karena pendidikan tinggi merupakan suatu hal yang sangat penting yang harus ditempuh siswa setelah lulus. Maka pengabdian dengan mendorong motivasi siswa guna menempuh pendidikan yang lebih tinggi sangat diperlukan. Adapun beberapa materi yang disampaikan dalam pengabdian masyarakat kepada siswa SMK APM (Asrama Pembina Masyarakat) diantaranya adalah berkaitan dengan keuntungan para siswa nantinya yang sudah disebutkan diatas.

Materi pertama para siswa diberikan informasi yang mendalam bahwa dengan kuliah maka pengetahuan mereka akan bertambah. Tidak hanya pengetahuan, keterampilan mereka juga akan bertambah. Pengetahuan dan keterampilan yang ditempuh dibangku SMK sangat terbatas. 
Wawasan yang diperoleh tidak sebanyak yang akan didapatkan ketika mereka meneruskan ke jenjang pendidikan tinggi (S-1). Siswa yang melanjutkan kuliah akan lebih matang dari segi pengetahuan maupun keterampilan dibandingkan lulusan SMK saja.

$\begin{array}{rrr}\text { Materi } & \text { kedua } & \text { adalah } \\ \text { penyampaian } & \text { tentang } & \text { standart }\end{array}$
terendah pendidikan. Saat ini sudah menjadi kewajiban setiap masyarakat untuk mengenyam pendidikan yang lebih baik. Masyarakat diharapkan untuk bisa mengenyam pendidikan tidak hanya dibangku SMA/SMK, tetapi untuk bisa terus meneruskan ke jenjang berikutnya (S-1) agar bangsa ini dapat bersaing ditingkat Internasional. Dengan rata-rata lulusan penduduknya adalah sarjana, dapat mengangkat Sumber Daya Manusia sebuah negara menjadi lebih baik karena pengetahuan dan keterampilan masyarakatnya berkualitas.

$$
\text { Materi ketiga yang }
$$

disampaikan kepada para siswa SMK APM (Asrama Pembina Masyarakat) adalah perihal peluang kerja yang semakin terbuka lebar. Dewasa ini, banyak lowongan pekerjaan yang mensyaratkan pendidikan terakhir adalah sarjana. Lulusan SMA/SMK akan kesulitan bersaing dengan para sarjana dalam hal memperoleh pekerjaan yang layak. Lulusan SMA/SMK mayoritas hanya mengisi pos-pos pekerjaan dilevel bawah. Oleh karena itu, dengan mengenyam pendidikan yang lebih tinggi (S-1) maka peluang untuk mencari pekerjaan yang baik akan semakin terbuka lebar. Materi ini disampaikan kepada siswa agar para siswa termotivasi untuk melanjutkan kuliah.

Selanjutnya dalam penyampaian materi yang keempat berkaitan dengan suatu cara pandang, maksutnya adalah seseorang yang mengenyam pendidikan yang lebih tinggi akan memiliki derajat yang baik dihadapan Tuhan dan dihadapan sesama manusia. Ini berkaitan dengan pengetahuan dan keterampilan tadi. Orang yang memiliki pengetahuan dan keterampilan yang bagus akan lebih disukai oleh sesama karena ilmunya dapat bermanfaat. Itulah kenapa 
dengan pendidikan tinggi, derajat seseorang semakin baik.

Materi yang kelima adalah memotivasi siswa dengan menyampaikan bahwa dengan gelar sarjana dapat membuat karir dalam pekerjaan lebih baik. Untuk mengejar karir yang baik, tidak cukup hanya berbekal kecerdasan dan prestasi, secara tidak langsung gelar sarjana sangat dibutuhkan. Seorang karyawan bawahan yang ingin mengejar karir menuju pimpinan, sudah diwajibkan untuk memiliki gelar sarjana. Karena standart terendah pekerjaan dengan jabatan tinggi diperusahaanperusahaan minimal pendidikannya wajib tingkat sarjana. Pos-pos jabatan tinggi mensyaratkan gelar minimal karyawannya adalah sarjana. Untuk itu, gelar sarjana sangat penting sekali untuk diperoleh guna menunjang karir yang lebih baik dalam bekerja.

Kegiatan pengabdian ini secara keseluruhan berlangsung dengan sangat baik. Para peserta dari siswa SMK APM (Asrama Pembina Masyarakat) memahami betul materi yang disampaikan. Mereka sangat antusias dengan kegiatan pengabdian ini. Para siswa banyak yang menyampaikan pertanyaanpertanyaan tentang pendidikan tinggi. Dimulai dengan cara memilih kampus yang baik, bagaimana untuk bisa kuliah jika tidak memiliki biaya, bagaimana cara mendapatkan beasiswa, serta bagaimana cara untuk bisa lolos ke kampus sesuai keinginan mereka. Pemateri menyampaikan jawaban dengan sejelas mungkin dari pertanyaanpertanyaan yang disampaikan. Para siswa SMK APM (Asrama Pembina Masyarakat) mengikuti kegiatan pengabdian ini sampai akhir acara, sehingga kegiatan acara pengabdian ini sudah dapat dikatakan berjalan dengan baik. Motivasi siswa yang bertambah juga menguatkan bahwa kegiatan ini telah berhasil.

\section{Evaluasi Kegiatan}

Kegiatan pengabdian dengan tema pendidikan yaitu memotivasi para siswa guna melanjutkan ke jenjang ke perguruan tinggi tidak hanya bisa dilakukan cukup sekali. Para siswa harus diberikan bimbingan yang rutin. Para guru 
menjadi alternatif lain dalam pemberian motivasi siswanya untuk dapat meneruskan kuliah.

Dosen pengabdian mengawali seminar dan selanjutnya para guru internal SMK APM (Asrama Pembina Masyarakat) dapat mengingatkan pentingnya melanjutkan kuliah didalam kegiatan belajar mengajarnya. Selain itu, tentu yang menjadi catatan bahwa kegiatan ini tidak berhenti disini, akan dilakukan pemantauan oleh dosen pengabdian untuk mengetahui perkembangan selanjutnya.

\section{DAFTAR PUSTAKA}

Fauzie, Yulu. https://www.cnnindonesia.com /gaya-hidup/20180607113429284-304214/bank-duniakualitas-pendidikan-indonesiamasih-rendah, diakses pada tanggal 11 April 2019 pukul 22.15 WIB).

Kurniadin, Didin dan Machali. 2016.

Manajemen Pendidikan :Konsep \& Prinsip Pengelolaan Pendidikan. Jogjakarta : Ar-Ruzz Media.
Putri, Tesha.

https://student.cnnindonesia.co m/edukasi/20180103112420445-266335/ada-apa-denganpendidikan-di-indonesia, diakses pada tanggal 11 April 2019 pukul 21.56 WIB.

Tim Ahli Seknas Jokowi. 2014. Jalan Kemandirian Bangsa. Jakarta : Gramedia Pustaka Utama.

Tim PGRI. 2014. Pendidikan Untuk Transformasi Bangsa. Jakarta : PT Kompas Media Nusantara. 